duties which our College performs for the suppression of quackery, and be a good pretext for upholding our venerable institution.

Believe me ever to be, "Your esteemed friend,

“Nov. 18, 1834." "H. $\mathrm{H}$.

\section{THE ANATONY ACT.}

SECOND LETTER OF PROFESSOR QUAIN, LOXDON UNIVERSITY.

\section{To the Editor of THE LANCET.}

Sin,-Before I proceed with any farther zemarks on the working of the Anatomy Act, it is due to $\mathrm{Mr}$. Stanley and $\mathrm{Mr}$. Mayo to explain a passage in my former letter, which appeàrs to admit of a construction different from what $I$ intended. After mentioning the resolution come to by the lecturers, it is observed that " there appeared a disposition to depart from the agreement thus entered into." This obviously is not correctly expressed. It was not an "agreement" that was entered into, but a "resolution" passed by a vote, and it was competent for any person to have that resolution set aside or not acted on if he thought fit. I am now glad to find that $I$ was mistaken in supposing any such disposition to exist, and trust this explanation will remove any disagreeable feeling to which the expression may have given rise. The paragraph relative to the anthorship of the letter in the Post cannot admit of any olher construction than that I was (and am still) convinced that neither of those gentlemen "had any thing to do with it ;" these are the words employed.

It was a brilliant conception of the writer in the Post, and worthy of the cause he espouses, to give something of * party colour to this affair of providing means for studying anatomy in the schools. But what sort of insight into the workings of the machinery of a government, or into the views or motives of men in the business of life, can that person possess who penned such a passage as this-" Nothing but Whig ingenuity could have suggested such a plan of com. petition as that now instituted between the several schools of London ?"

Whiggism, indeed, must be sunk beneath the level of meanness, were it in anywise to be nixed up with such paltry concerns. But when I look a little farther on, and read the paragraph in which this writer's " remedy" is put forth: when $I$ fird him anxious that lecturers and teachers should proceed forthwith amongst the parishes, and there bestir themselyes, thus committing the supply of the schools to a chance medley - a mere scramble-I can scarcely 1 efrain from observing in his own words, mutatis mutandis-that nothing but a body-snatcher's ingenuity could have suggested such a plan of competition amongst the schools; sed hactenus hac.

To recommend exertion sounds well, and seems plausible; it carries something bustling and business-like with it. Let us try this proposal as we would test any other project or hypothesis; let us for a moment suppose it to be adopted, and then consider how it would work. As the past is generally the best guarantee for the future, so an instance of what has already been done, will enable us clearly to see what may be done at a future time; and as exertion has various shades of merit, according to the purposes to which it is directed, I will give you a short essay upon "exertion"- - that single word being the theme.

Exertion the first. Not very long after the passing of the Anatomy Act, the board in a neighbouring parish passed a vote permitting unclaimed bodies to be examined anatomically in the London tris. versity. We did not think after the passing of such a vote that it was necessary to exercise any particular vigilance in the parish, not expecting that any "exertion" would be made to disturb the resolution which the board had come to, at least during the first session. But in a month or two we did hear that an "exertion" was made to induce the board to reconsider their vote; a special claim being set up on behalf of another school. We learned from a member of the board that an application from King's College had been presented to them, signed by $\mathrm{Mr}$. Smith, the secretary. I cannot at this distance of time recollect what was required by Mr. Smith; I cannot say whether he asked to have the previous vote set. aside in favour of the King's College, or merely to be admitted to a participation in common with the Cniversity. The matter was discussed at the board, and notwithstanding the active " exertions" which were made, they saw no reason for disturbing the previous arrangement. Upon this "exertion" I shall make no comment, but with your leave I will put a few questions for the consideration of the reader. Is it usual when a party is in possession of anything, no matter what, for another to go and make an offer with a view to the possession of, or participation in, that thing, be it what it may, without giving a notice or intimation of any kind to the party in possession? Would it have been a fitting sourtesy, on 
the part of the secretary of King's College, to have written to the secretary of the University, when he was about to make the application here referred to, giving him an intimation of his intention? Was it not due, in common civility, from the lecturers in King's College to those in the London University, to have written a note to inform them of their intention to take the opinion of the board again, with a view to alter or reverse it? Why were these courtesies, common-place as they are even in the ordinary intercourse of life, forgotten or omitted? Perhaps they were forgotten; the omission might have been accidental. Be it so; read on.

Exertion the second.-Shortly after the commencement of the present session, a vigorous "exertion" was made in the parish just alluded to, to have the vote in favour of the University school set aside, and a resolution passed in favour of the school in St.Bartholomew's Hospital. We received no intimation whatever that any measure of the kind was contemplated, until " exertion" had done all it could effect. We were, however, not the persons to be tripped up so readily, even though taken unawares, and we bestirred ourselves accordingly. The matter was discussed at three or four successive meetings, and whilst much "exertion" was being made on each side, the King's Col. lege came forward with a similar applica. tion. I cannot say whether, on this occasion, the latter institution was represented by Mr. Smith or by whom. It was not for me to make any suggestion to those parties - I mean the applicants on behalf of King's College or St.Bartholomew's Hospital. I was precluded from holding even any communication with them, inasmuch as, in this instance, as in the former, no intimation was given to me or to any person with whom I am connected, of their " intention to make another "exertion" in the parish, or subject the board to the annoyance of another canvass. This " exertion," as well as the former, proved unavailing. The vote remains undisturbed. I mention the circumstance merely to show that if the proposal made by the writer in the Morming Post were adopted, and if the lecturers were now directed to start off in a race of competition amongst the parishes, we should be very likely to have a fair share in such a scramble. But is this the sort of competition to which schools and school-men are to be subjected? Are they to be exposed to a collision at once unseemly and indecent? Are the ordinary civilities of life to be forgotten? Are the parochial authorities to be thus exposed to ceaseless solicitation by lecturcrs and teachers? Is the time which they can spare for the public service to be wasted in attending to applications for altering or rescinding votes which they had passed but a few months before? If this line of conduct were to be pursued by lec. turers one to the other, what sort of feeling would grow up between them? In what estimation would they be held by the public? What is the lesson which would be taught to pupils by this sort of conduct? Is it or is it not that when they proceed to their different destinations in life, they may hustle out of their way their rivals and competitors by any means which would serve the purpose and justify the expedients to which they may resort by appealing to the acts of their masters and the examples which they had set them? I do not pause for the answers which any thinking person will give to these questions. They will readily suggest themselves to every man's mind, and present at one view the immediate effects and future consequences which must spring up, were the lecturers all to proceed with their "exertions" amongst the parishes.

Exertion the third.-From barter to purchase is but a step. It is the natural transition which takes place both in the affairs of individuals and of nations in the management of their exchanges with one another. Barter is conducted on the principle of giving a "quil pro quo." I have mentioned some instances of this. When a parish board is called on by a gentleman in the Borough to give up unclaimed bodies to a particular school, because the hospital to which that school is attached affords certain advantages to the parish, is or is not that a case of simple barter? When a gentleman in the city offers to accommodate the sick of another parish in his hospital, is not that offering a "quid pro quo?" Does any great interval separate this primitive sort of barter from the more direct method of purchase? About two years ago, when all the lecturer's were " exerting" themselves amongst the parishes, it so happened that Mr. Stanley and Mr. Girainger met together in the board-room of a parish which they had previously canvassed. It was intimated to Mr. Grainger, by a member of the board, that certain alvantages were held out to them if they would pass a vote in farour of St. Bartholomen's Hospital, viz. that their sick poor would be accommodated in the hospital if the unclaimed bodies were given up to the school. He did not say by whom the offer was made. He concluded his remarks by asking Mr. Grainger whether he could give them any similar accommodation; to which Mr. Grainger promptly replied that he could not. When 
the affair took this aspect, Mr. G. naturally enough concluded that a vote would be passed in favour of $S t$. Bartholomew's Hospital. But there was a sufficient quantity of good sense and right feeling amongst the members of the hoard to enable them to see the matter in its proper light, and they passed a vote in favour of the school in st. Bartholomew's Hospital, and that in Webb Street.

Matters went on smoothly enough for a while; a certain parish functionary " performed" the usual " undertakings." When the bill for these came in to $\mathrm{Mr}$. Grainger he found a charge made against him of $5 l$, or nearly as much, for each funeral. To this he objected, but was promptly informed that Mr. Stanley made no objection to pay the like sum. The affair was referred to the Inspector, who had the charge reduced to three pounds or guineas. I have merely to add that $\mathrm{Mr}$. Grainger was not called on to pay a second bill. Why was this? it will be asked. I can offer no explanation save this - that we all know there is a considerable differ ence in the value of a customer at three pounds and one at five, and dull indeed must be the comprehension of him who does not perceive that this sort of "argumentum ad crumenam," disguised in some form or other, will constantly be resorted to when the lecturers proceed to "exert" themselves amongst the parishes. "To this complexion must it come at last."

It will be asked, Why bring these circumstances before the public? I answer, plainly, I have no object save one, viz., to determine a public question ;-to ascertain the principle upon which the Schools of Anatomy are to be conducted; - to enable the medical profession, the lecturers on Anatomy, and the friends of the Schools, to decide which of two methods of proceeding they will adopt. By one it is proposed that all the bodies obtained under the provisions of the Anatomy Act shall be distributed amongst the schools according to the number of pupils in each. By the other, it is proposed that the lecturers shall be left to " exert" themselves amongst the parishes in order to obtain supplies in the best manner they can. Upon the determination of this question depends another-whether the profession of the anatomist is to be such as to befit a gentleman, or sunk to that state in which it would be adapted only to the taste and habit of a resurrectionist. Are we to be committed to ceaseless contention? Are we to compass our ends by barter or even by purchase? If I was not deliberately convinced that matters had come to such a pass as to demand imperatively the opinion of the medical profession, of the public, and of the lectarers upon each and every of these questions, I would not have trespassed upon your space or intruded myself upon the attention of your readers. It is not my custom to do either. Neither is it with me a usage, in public or in private, to speak otherwise than with kindness and consideration of my professional brethren. If the tone of these letters be unpleasant to any parties, it has been forced upon me by the line of conduct which has been pursued towards me, and those with whom I am connected. It has been imputed to us that we have sought undue advantages under the Act of Parliament, by secret influence. This report has beeri studiously propagated in a variety of places. When many persons were disposed to believe it, by reason of the frequency of its repetition, then came out the manifesto urging the adoption of the " remedy," that all the lecturers should start upon a new course of " exertion." Thus we should have been placed in a false position with the public, being represented as a "favoured" school under the influence of Whig ingenuity, and as such, entitled to no consideration under a new order of things. I am, Sir, yours, \&c.

\section{Great Coram-street, Nov. 25th, 1834.}

\section{EDINBURGI AND GLASGOW MEDICAL} JOBBERS.

\section{To the Editor of The Lancet.}

SIR,-The remark made in a late number of THE LANCET that the appointment of Dr. David Cragie to the Inspectorship of Anatomy for Edinburgh was not a Whig job, is founded on error. It was perhaps not a job of the Edinburgh Whigs, who wished it for one of their own dependants, but Craigie's appointment was, nevertheless, a Whig job. Dr. David Craigie is a person about whose political principles nobody cares, but his appointment to the office above referred to was as complete a job as ever was perpetuated, and it was accomplished through the instrumentality of Dr. Lee, the Lauthian pirate, formerly a "divine," and some time a tutor in the houschold of Lord Melbourne. Your " Edinburgh Correspondent's" remark on this subject in a late number of THE LAN. cET, leads me to suspect that he has been humbugged by some of the wily Edinburgh Whigs with regard to Dr. Craigie.

Was it not by intriguing with Lord Melbourne that Dr. Lee got appointed to the Chair of Midwifery in the University of 